Article

\title{
The Serum and Saliva Proteome of Dogs with Diabetes Mellitus
}

\author{
Lorena Franco-Martínez ${ }^{1}\left(\mathbb{D}\right.$, Andrea Gelemanović ${ }^{2}$, Anita Horvatić ${ }^{3}$ (D), \\ María Dolores Contreras-Aguilar ${ }^{1} \mathbb{1}$, Vladimir Mrljak ${ }^{4}{ }^{\circledR}$, José Joaquín Cerón ${ }^{1}$, \\ Silvia Martínez-Subiela ${ }^{1, *(\mathbb{D})}$ and Asta Tvarijonaviciute ${ }^{1}$ (D) \\ 1 Interdisciplinary Laboratory of Clinical Pathology, Interlab-UMU, Regional Campus of International \\ Excellence 'Campus Mare Nostrum', University of Murcia, 30100 Murcia, Spain; \\ lorena.franco2@um.es (L.F.-M.); mariadolores.contreras@um.es (M.D.C.-A.); jjceron@um.es (J.J.C.); \\ asta@um.es (A.T.) \\ 2 Mediterranean Institute for Life Sciences (MedILS), 21000 Split, Croatia; agelemanovic@medils.hr \\ 3 Faculty of Food Technology and Biotechnology, University of Zagreb, Pierottijeva 6, 10000 Zagreb, Croatia; \\ horvatic.ani@gmail.com \\ 4 Faculty of Veterinary Medicine, University of Zagreb, Heinzelova 55, 10000 Zagreb, Croatia; vmrljak@vef.hr \\ * Correspondence: silviams@um.es; Tel.: +34-86-888-7168
}

Received: 26 October 2020; Accepted: 25 November 2020; Published: 1 December 2020

check for updates

Simple Summary: The present study describes for the first time the differences in the serum and saliva proteomes between healthy dogs and dogs with diabetes mellitus by a high- throughput proteomic approach. More than 1000 proteins were identified, and 16 proteins in serum and 26 in saliva showed significant changes between both groups. Additionally, pathways that showed changes were discussed in order to improve the understanding of the pathophysiology of the disease and one protein in serum (haptoglobin) was successfully verified. The results of the present study could be a source of potential biomarkers for canine diabetes mellitus in saliva and serum and also contribute to increase the knowledge of the pathophysiology of the disease.

Abstract: This study aims to evaluate the changes in salivary and serum proteomes that occur in canine diabetes mellitus type- $1(\mathrm{DM})$ through a high-throughput quantitative proteomic analysis. The proteomes of 10 paired serum and saliva samples from healthy controls (HC group, $n=5$ ) and dogs with untreated DM (DM group, $n=5$ ) were analyzed using Tandem Mass Tags (TMT)-based proteomic approach. Additionally, 24 serum samples from healthy controls and untreated DM were used to validate haptoglobin in serum. The TMT analysis quantified 767 and 389 proteins in saliva and serum, respectively. Of those, 16 unique proteins in serum and 26 in saliva were differently represented between DM and HC groups. The verification of haptoglobin in serum was in concordance with the proteomic data. Our results pointed out changes in both saliva and serum proteomes that reflect different physiopathological changes in dogs with DM. Although some of the proteins identified here, such as malate dehydrogenase or glyceraldehyde-3-phosphate dehydrogenase, were previously related with DM in dogs, most of the proteins modulated in serum and saliva are described in canine DM for the first time and could be a source of potential biomarkers of the disease. Additionally, the molecular function, biological process, pathways and protein class of the differential proteins were revealed, which could improve the understanding of the disease's pathological mechanisms.

Keywords: canine diabetes mellitus; gel-free proteomics; high-resolution mass spectrometry; tandem mass tags; type 1 diabetes 


\section{Background}

Canine diabetes mellitus (DM) is a common spontaneous endocrine disorder in middle age to geriatric dogs [1]. Its estimated prevalence is between 0.2 to $1.2 \%$, being higher in genetically predisposed breeds such as Cairn Terriers, Tibetan Terriers or Samoyeds [2]. According to data reported by Banfield's State of Pet Health [3], canine DM showed a 79.7\% increase in its incidence from 2006 to 2019 in the United States, affecting more than 2.5 million canine patients worldwide (Benfield's State of Pet Health, 2016 Report). Canine DM has been regarded as similar to human type 1 DM, which is related to $\beta$-cell damage and insulin deficiency [4] and dogs have been proposed as feasible animal models for human DM [5].

DM is characterized by a persistent hyperglycemia and insulin deficiency, consequence of a massive pancreatic $\beta$-cell loss. These factors lead to polyuria, polydipsia, polyphagia, lethargy and weight loss [6]. The most common treatment for canine diabetes mellitus is the life-long subcutaneous injections of insulin twice a day. In untreated animals or when the disease cannot be adequately controlled, it can lead to potentially life-threatening diabetic ketoacidosis [7]. Additionally, there are common comorbidities and complications of canine DM, such as retinopathy, cataracts, hyperadrenocorticism, pancreatitis, dermatitis, otitis, urinary tract infections or hypothyroidism [7].

Saliva is a valuable body fluid that can reflect systemic and local health-conditions. Compared to blood, saliva collection is a non-invasive procedure that is easier, safer, less stressful and pain-free [8]. In humans changes in the proteome of saliva have been used to identify potential biomarkers of a variety of diseases such as cancer [9]. Also some reports indicate that saliva has a diagnostic and monitoring value in DM [10-12], and changes caused by diabetes mellitus in serum [13] and saliva [14-16] proteomes in humans have been reported. In dogs, gel-free proteomics approaches, including Tandem Mass Tag (TMT), have been successfully used in serum and/or saliva to study changes associated to obesity [17] or infectious diseases such as parvoviral enteritis [18] and leishmaniosis [19-21]. However, to the best of the author's knowledge, there are no reports about studies addressing possible changes in saliva and serum proteomes in dogs with DM.

The aims of the present study were to detect the possible changes in paired saliva and serum proteomes in dogs with DM in comparison to healthy ones by using TMT-based technology. Those changes could contribute to gain knowledge of DM pathogenesis and the discovery of potential novel biomarkers of the disease.

\section{Results}

\subsection{Proteomic Analysis in Serum}

A total of 389 serum proteins remained for statistical analysis after removing of missing data, outliers and proteins with less of two unique peptides (Supplementary Materials Table S3 and Figure S1). Wilcoxon-Mann-Whitney test identified 31 proteins (corresponding to 16 unique genes) with differential abundances between HC and DM groups with $p$-value $<0.05$, which are summarized after the removal of duplicates and isoforms in Table 1 and Figure S2.

Table 1. Proteins in serum with significantly differential abundances between healthy controls (HC) and dogs with diabetes mellitus (DM) identified using a Tandem Mass Tags (TMT)-based proteomic analysis.

\begin{tabular}{|c|c|c|c|c|c|}
\hline $\begin{array}{l}\text { Gene } \\
\text { Symbol }\end{array}$ & Description & $p$-Value & $\begin{array}{l}\text { Fold } \\
\text { Change }\end{array}$ & $\begin{array}{c}\text { Mean } \\
\text { (SD) } \\
\text { Healthy }\end{array}$ & $\begin{array}{c}\text { Mean } \\
\text { (SD) } \\
\text { Diseased }\end{array}$ \\
\hline \multicolumn{6}{|c|}{ Proteins down-regulated in DM when compared to HC } \\
\hline IL13RA2 & $\begin{array}{l}\text { Interleukin-13 receptor subunit alpha-2 precursor } \\
\text { [Canis lupus familiaris] }\end{array}$ & 0.016 & 0.426 & $\begin{array}{c}0.941 \\
(1.062)\end{array}$ & $\begin{array}{c}0.569 \\
(0.032)\end{array}$ \\
\hline IGHG & $\begin{array}{l}\text { Immunoglobulin gamma heavy chain D } \\
\text { [Canis lupus familiaris] }\end{array}$ & 0.016 & 0.426 & $\begin{array}{c}0.941 \\
(1.062)\end{array}$ & $\begin{array}{c}0.569 \\
(0.032)\end{array}$ \\
\hline
\end{tabular}


Table 1. Cont.

\begin{tabular}{|c|c|c|c|c|c|}
\hline $\begin{array}{l}\text { Gene } \\
\text { Symbol }\end{array}$ & Description & $p$-Value & $\begin{array}{l}\text { Fold } \\
\text { Change }\end{array}$ & $\begin{array}{c}\text { Mean } \\
\text { (SD) } \\
\text { Healthy }\end{array}$ & $\begin{array}{c}\text { Mean } \\
\text { (SD) } \\
\text { Diseased }\end{array}$ \\
\hline IGLL & $\begin{array}{l}\text { Immunoglobulin lambda-1 light chain } \\
\text { [Canis lupus familiaris] }\end{array}$ & 0.016 & 0.519 & $\begin{array}{l}1.235 \\
(0.037)\end{array}$ & $\begin{array}{c}0.754 \\
(0.173)\end{array}$ \\
\hline VPREB1 & $\begin{array}{l}\text { Immunoglobulin iota chain-like } \\
\text { [Canis lupus familiaris] }\end{array}$ & 0.016 & 0.538 & $\begin{array}{l}1.179 \\
(0.06)\end{array}$ & $\begin{array}{c}0.673 \\
(0.138)\end{array}$ \\
\hline TFRC & $\begin{array}{l}\text { Transferrin receptor } \\
\text { [Canis lupus familiaris] }\end{array}$ & 0.016 & 0.664 & $\begin{array}{c}1.149 \\
(0.048)\end{array}$ & $\begin{array}{c}0.715 \\
(0.2)\end{array}$ \\
\hline GSN & $\begin{array}{c}\text { Gelsolin } \\
\text { [Canis lupus familiaris] }\end{array}$ & 0.032 & 0.671 & $\begin{array}{c}1.191 \\
(0.117)\end{array}$ & $\begin{array}{c}0.795 \\
(0.103)\end{array}$ \\
\hline IGHV & $\begin{array}{l}\text { Immunoglobulin heavy chain variable region } \\
\text { [Canis lupus familiaris] }\end{array}$ & 0.032 & 0.718 & $\begin{array}{l}1.029 \\
(0.085)\end{array}$ & $\begin{array}{c}0.884 \\
(0.315)\end{array}$ \\
\hline ITIH2 & $\begin{array}{c}\text { Inter-alpha-trypsin inhibitor heavy chain } \mathrm{H} 2 \\
\text { [Canis lupus familiaris] }\end{array}$ & 0.008 & 0.735 & $\begin{array}{l}1.076 \\
(0.112)\end{array}$ & $\begin{array}{l}0.916 \\
(0.15)\end{array}$ \\
\hline ITIH4 & $\begin{array}{l}\text { Inter-alpha-trypsin inhibitor heavy chain } \mathrm{H} 4 \\
\text { [Canis lupus familiaris] }\end{array}$ & 0.032 & 0.796 & $\begin{array}{c}0.876 \\
(0.071)\end{array}$ & $\begin{array}{c}0.704 \\
(0.056)\end{array}$ \\
\hline ITIH1 & $\begin{array}{l}\text { Inter-alpha-trypsin inhibitor heavy chain } \mathrm{H} 1 \\
\text { [Canis lupus familiaris] }\end{array}$ & 0.032 & 0.809 & $\begin{array}{c}1.124 \\
(0.043)\end{array}$ & $\begin{array}{c}0.881 \\
(0.064)\end{array}$ \\
\hline $\mathrm{A} 2 \mathrm{M}$ & $\begin{array}{l}\text { Alpha-2-macroglobulin } \\
\text { [Canis lupus familiaris] }\end{array}$ & 0.008 & 0.813 & $\begin{array}{l}1.031 \\
(0.076)\end{array}$ & $\begin{array}{c}0.896 \\
(0.157) \\
\end{array}$ \\
\hline APOD & $\begin{array}{l}\text { Apolipoprotein D } \\
\text { [Canis lupus familiaris] }\end{array}$ & 0.032 & 0.841 & $\begin{array}{c}0.999 \\
(0.144)\end{array}$ & $\begin{array}{c}0.86 \\
(0.072)\end{array}$ \\
\hline PLG & $\begin{array}{l}\text { Plasminogen } \\
\text { [Canis lupus familiaris] }\end{array}$ & 0.032 & 0.883 & $\begin{array}{c}1.09 \\
(0.071)\end{array}$ & $\begin{array}{c}0.944 \\
(0.034) \\
\end{array}$ \\
\hline \multicolumn{6}{|c|}{ Proteins up-regulated in DM when compared to HC } \\
\hline С4BPB & $\begin{array}{l}\text { C4b-binding protein beta chain } \\
\text { [Canis lupus dingo] }\end{array}$ & 0.032 & 1.341 & $\begin{array}{c}1.03 \\
(0.126)\end{array}$ & $\begin{array}{l}1.343 \\
(0.146) \\
\end{array}$ \\
\hline MGAM & $\begin{array}{l}\text { Maltase-glucoamylase, intestinal } \\
\text { [Canis lupus familiaris] }\end{array}$ & 0.016 & 1.367 & $\begin{array}{c}0.83 \\
(0.026)\end{array}$ & $\begin{array}{c}1.061 \\
(0.242)\end{array}$ \\
\hline $\mathrm{HP}$ & $\begin{array}{l}\text { Haptoglobin heavy chain } \\
\text { [dogs, Peptide, } 245 \text { aa] }\end{array}$ & 0.032 & 1.584 & $\begin{array}{l}0.537 \\
(0.15)\end{array}$ & $\begin{array}{l}0.972 \\
(0.21)\end{array}$ \\
\hline
\end{tabular}

IQR: interquartile range.

Of the 16 unique proteins differently modulated between HC and DM groups, 13 were down-regulated and three were up-regulated in DM. The proteins differently expressed in serum between HC and DM groups were used for subsequent bioinformatics analyses in terms of functional clusters, according to the PANTHER classification system, as shown in Figure 1. 
Saliva

\section{PANTHER GO-Slim Molecular Function}

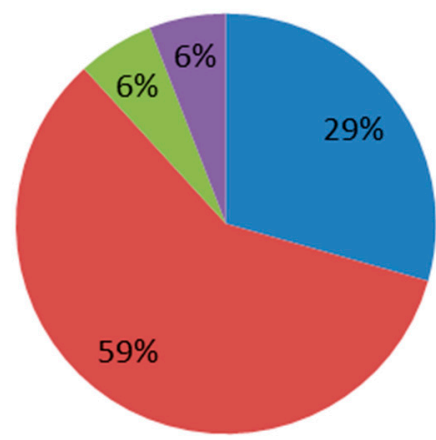

ainding (GO:0005488)

catalytic activity (GO:0003824)

molecular function regulator (G0:0098772)

nolecular transducer activity (GO:0060089)

\section{PANTHER GO-Slim Biological Process}

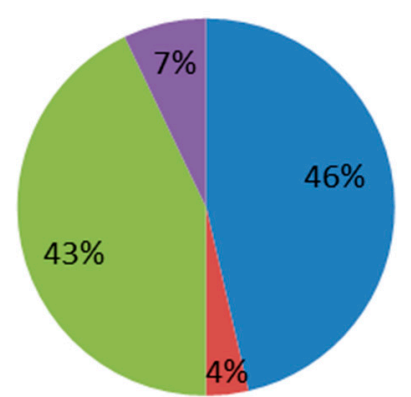

n cellular process (G0:0009987)

n localization (GO:0051179)

metabolic process (G0:0008152)

a response to stimulus (G0:0050896)

\section{Serum}

\section{PANTHER GO-Slim Molecular Function}

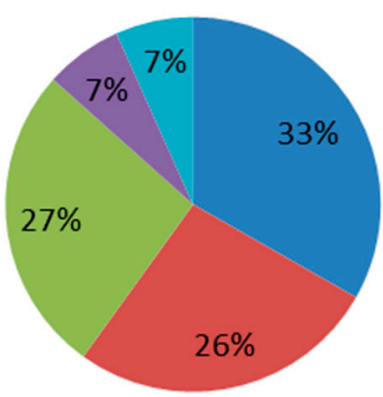

a binding (GO:0005488)

natalytic activity (GO:0003824)

molecular function regulator (G0:0098772)

molecular transducer activity (G0:0060089)

n structural molecule activity (G0:0005198)

\section{PANTHER GO-Slim Biological Process}

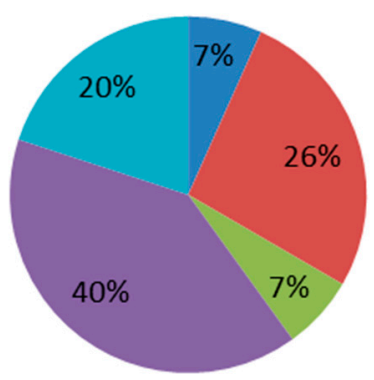

a biological regulation (GO:0065007)

n cellular process (GO:0009987)

n immune system process (GO:0002376)

metabolic process (GO:0008152)

n response to stimulus (GO:0050896)

Figure 1. Cont. 
PANTHER Pathway

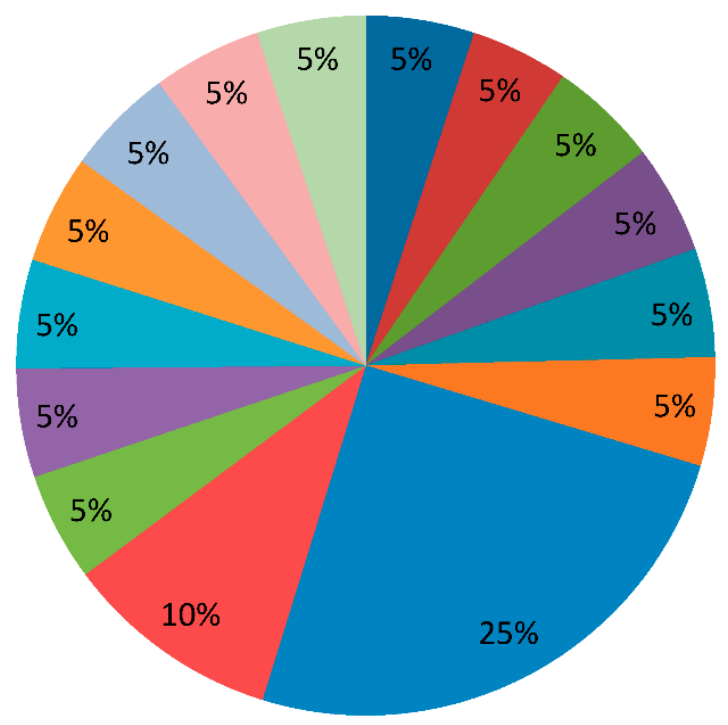

- Apoptosis signaling pathway (P00006)

- Cytoskeletal regulation by Rho GTPase (P00016)

De novo purine biosynthesis (P02738)

De novo pyrimidine deoxyribonucleotide biosynthesis (P02739)

- De novo pyrimidine ribonucleotides biosythesis (P02740)

Dopamine receptor mediated signaling pathway (P05912)

Glycolysis (P00024)

- Huntington disease (P00029)

- Inflammation mediated by chemokine and cytokine signaling pathway (P00031)

- Integrin signalling pathway (P00034)

nicotine pharmacodynamics pathway (P06587)

Parkinson disease (P00049)

Pentose phosphate pathway (P02762)

Salvage pyrimidine ribonucleotides (P02775)

TCA cycle (P00051)

\section{PANTHER Pathway}

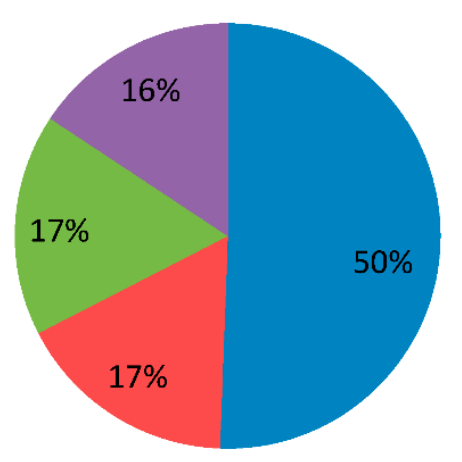

- Blood coagulation (P00011)

n FAS signaling pathway (P00020)

- Interleukin signaling pathway (P00036)

- Plasminogen activating cascade (P00050)

Figure 1. Cont. 
PANTHER Protein Class

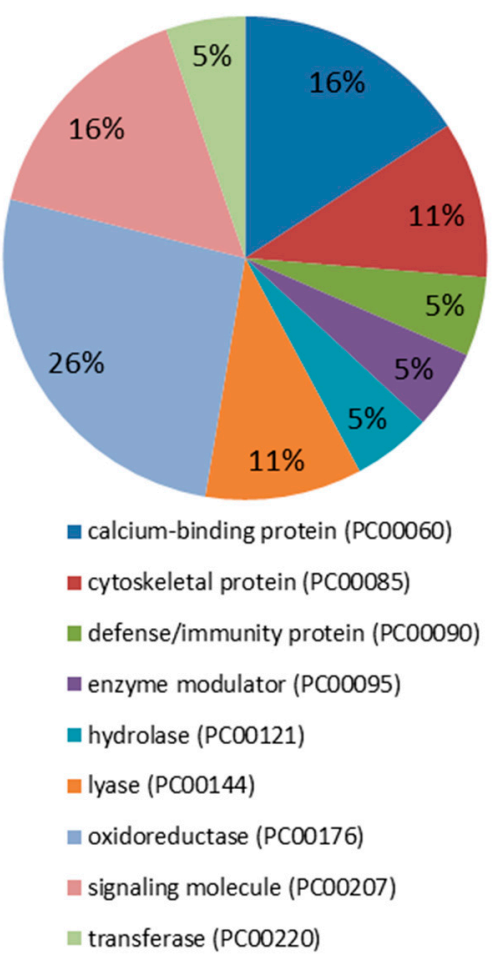

\section{PANTHER Protein Class}

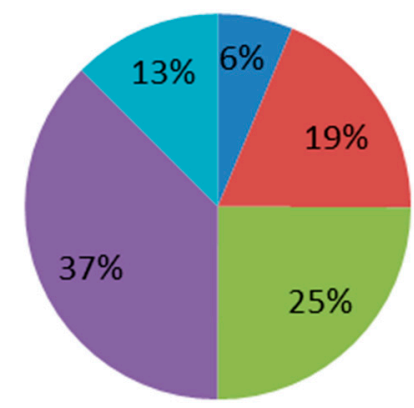

口 cytoskeletal protein (PC00085)

- defense/immunity protein (PC00090)

nenzyme modulator (PCO0095)

nydrolase (PC00121)

- signaling molecule (PCOO207)

Figure 1. Pie charts showing the molecular function, biological process, pathway and protein class expressed as a percentage of the total differentially expressed proteins between HC and DM groups in serum (right) and saliva (left) based on the PANTHER classification system (http://www.pantherdb.org).

Proteins were distributed within five different molecular functions: binding (GO:0005488) (33.3\%), catalytic activity (GO:0003824) (26.7\%), molecular function regulator (GO:0098772) $(26.7 \%)$, molecular transducer activity (GO:0060089) (6.7\%) and structural molecule activity (GO:0005198) (6.7\%). They participate in five molecular processes, namely metabolic process (GO:0008152) $(40 \%)$, cellular process (GO:0009987) (26.7\%), response to stimulus (GO:0050896) (20\%), immune system process (GO:0002376) (6.7\% pl) and biological regulation (GO:0065007) $(6.7 \%)$. Four pathways were found to be related to those differentially expressed proteins: blood coagulation (P00011) (42.9\%), FAS signaling pathway (P00020) (14.3\%), interleukin signaling pathway (P00036) $(14.3 \%)$ and plasminogen activating cascade (P00050) (13.3\%). Lastly, five proteins classes were identified, being hydrolase (PC00121) the most represented (37.5\%), followed by enzyme modulator (PC00095) (25\%), defense/immunity protein (PC00090) (18.7\%), signaling molecule (PC00207) (12.5\%) and cytoskeletal protein (PC00085) (6.3\%).

\subsection{Proteomic Analysis in Saliva}

After removing missing data, outliers, not more than $<5 \%$ FDR and proteins with less of two unique peptides, 767 proteins remained for statistical analysis (Table S4 and Figure S3). Wilcoxon-Mann-Whitney test identified 50 proteins (corresponding to 26 unique genes) with differential abundances between HC and DM groups with $p$-value $<0.05$, which are summarized after the removal of duplicates and isoforms in Table 2 and Figure S4. Out of the 26 unique proteins modulated in saliva, five proteins were down-regulated in dogs with $\mathrm{DM}$, while twenty-one were up-regulated. 
Table 2. Proteins in saliva with significantly differential abundances between healthy controls (HC) and dogs with diabetes mellitus (DM) identified using TMT-based proteomic analysis.

\begin{tabular}{|c|c|c|c|c|c|}
\hline $\begin{array}{l}\text { Gene } \\
\text { Symbol }\end{array}$ & Description & $p$-Value & $\begin{array}{l}\text { Fold } \\
\text { Change }\end{array}$ & $\begin{array}{l}\text { Mean (IQR) } \\
\text { Healthy }\end{array}$ & $\begin{array}{c}\text { Mean (IQR) } \\
\text { Diseased }\end{array}$ \\
\hline \multicolumn{6}{|c|}{ Proteins down-regulated in DM when compared to HC } \\
\hline A1BG & $\begin{array}{l}\text { Alpha-1B-glycoprotein } \\
\text { [Canis lupus familiaris] }\end{array}$ & 0.016 & 0.438 & $0.932(0.541)$ & $0.498(0.038)$ \\
\hline KLK1 & $\begin{array}{l}\text { Kallikrein-1-like } \\
\text { [Canis lupus dingo] }\end{array}$ & 0.029 & 0.452 & $1.599(0.094)$ & $0.753(0.194)$ \\
\hline $\mathrm{ENO} 2$ & $\begin{array}{l}\text { Gamma-enolase } \\
\text { [Canis lupus dingo] }\end{array}$ & 0.032 & 0.469 & $1.661(1.274)$ & $1.121(0.335)$ \\
\hline CANF2 & $\begin{array}{c}\text { Precursor Can f II } \\
\text { [Canis lupus familiaris] }\end{array}$ & 0.031 & 0.47 & $2.459(0.632)$ & $0.981(0.367)$ \\
\hline GAPDH & $\begin{array}{l}\text { Glyceraldehyde-3-phosphate dehydrogenase } \\
\text { [Canis lupus familiaris] }\end{array}$ & 0.016 & 0.667 & $1.058(0.467)$ & $0.824(0.004)$ \\
\hline \multicolumn{6}{|c|}{ Proteins up-regulated in DM when compared to HC } \\
\hline MDH1 & $\begin{array}{l}\text { Malate dehydrogenase, cytoplasmic } \\
\text { [Canis lupus familiaris] }\end{array}$ & 0.016 & 1.313 & $0.657(0.118)$ & $0.91(0.123)$ \\
\hline IPSG & $\begin{array}{l}\text { Double-headed protease inhibitor, } \\
\text { submandibular gland } \\
\text { [Canis lupus familiaris] }\end{array}$ & 0.029 & 1.39 & $0.698(0.092)$ & $0.854(0.206)$ \\
\hline TPI1 & Triosephosphate isomerase & 0.032 & 1.445 & $0.851(0.194)$ & $0.985(0.113)$ \\
\hline TKT & $\begin{array}{c}\text { Transketolase } \\
\text { [Canis lupus familiaris] }\end{array}$ & 0.032 & 1.463 & $0.648(0.397)$ & $1.061(0.086)$ \\
\hline CALM3 & $\begin{array}{l}\text { Calmodulin-3 } \\
\text { [Canis lupus dingo] }\end{array}$ & 0.016 & 1.584 & $0.788(0.199)$ & $1.088(0.054)$ \\
\hline NME2 & $\begin{array}{l}\text { Nucleoside diphosphate kinase B } \\
\text { [Canis lupus familiaris] }\end{array}$ & 0.016 & 1.624 & $0.547(0.248)$ & $1.052(0.139)$ \\
\hline HSPA8 & $\begin{array}{l}\text { Heat shock cognate } 71 \text { kDa protein } \\
\text { [Canis lupus familiaris] }\end{array}$ & 0.032 & 1.666 & 0.585 (0.39) & $1.081(0.175)$ \\
\hline YWHAE & $\begin{array}{l}\text { 14-3-3 protein epsilon } \\
\text { [Canis lupus familiaris] }\end{array}$ & 0.032 & 1.671 & $0.672(0.254)$ & $1.135(0.17)$ \\
\hline LCP1 & $\begin{array}{c}\text { Plastin-2 } \\
\text { [Canis lupus familiaris] }\end{array}$ & 0.016 & 1.684 & $0.538(0.622)$ & $1.111(0.161)$ \\
\hline YWHAQ & $\begin{array}{l}\text { 14-3-3 protein theta } \\
\text { [Canis lupus dingo] }\end{array}$ & 0.032 & 1.702 & $0.785(0.286)$ & $1.191(0.193)$ \\
\hline CALM2 & $\begin{array}{c}\text { Calmodulin-2 } \\
\text { [Canis lupus dingo] }\end{array}$ & 0.008 & 1.822 & $0.88(0.298)$ & $1.341(0.488)$ \\
\hline S100A2 & $\begin{array}{c}\text { Protein S100-A2 } \\
{[\text { Canis lupus dingo] }}\end{array}$ & 0.016 & 1.840 & $0.541(0.151)$ & $0.962(0.03)$ \\
\hline MDH2 & $\begin{array}{l}\text { Malate dehydrogenase, mitochondrial-like } \\
\text { [Canis lupus familiaris] }\end{array}$ & 0.008 & 1.969 & $0.447(0.139)$ & $0.88(0.281)$ \\
\hline CANF1 & Major allergen Can $\mathrm{f} 1$ & 0.016 & 1.978 & $0.492(0.041)$ & $0.88(0.461)$ \\
\hline FLNA & $\begin{array}{c}\text { Filamin-A } \\
\text { [Canis lupus familiaris] }\end{array}$ & 0.032 & 2.102 & $0.464(0.437)$ & $1.163(0.117)$ \\
\hline GSTA4 & $\begin{array}{c}\text { Glutathione S-transferase A4-like } \\
\text { [Canis lupus familiaris] }\end{array}$ & 0.032 & 2.105 & $0.43(0.19)$ & $1.082(0.258)$ \\
\hline PTMA & $\begin{array}{l}\text { Prothymosin alpha } \\
\text { [Canis lupus familiaris] }\end{array}$ & 0.032 & 2.348 & $0.432(0.155)$ & $1.056(0.286)$ \\
\hline S100A11 & $\begin{array}{c}\text { Protein S100-A11 } \\
\text { [Canis lupus familiaris] }\end{array}$ & 0.032 & 2.451 & $0.396(0.246)$ & $1.136(0.528)$ \\
\hline ARPC4 & $\begin{array}{l}\text { Actin-related protein } 2 / 3 \text { complex subunit } 4 \\
\text { [Canis lupus familiaris] }\end{array}$ & 0.016 & 2.723 & $0.246(0.384)$ & $1.161(0.118)$ \\
\hline S100A9 & $\begin{array}{c}\text { Protein S100-A9 } \\
\text { [Canis lupus familiaris] }\end{array}$ & 0.032 & 2.856 & $0.254(0.442)$ & $1.327(0.417)$ \\
\hline S100A12 & $\begin{array}{l}\text { Protein S100-A12-like } \\
\text { [Canis lupus dingo] }\end{array}$ & 0.032 & 2.963 & $0.268(0.526)$ & $1.199(0.45)$ \\
\hline
\end{tabular}


These differentially expressed proteins in saliva between HC and DM groups were used for subsequent bioinformatics analysis in terms of functional clusters, according to the PANTHER classification system, as shown in Figure 1. Proteins were distributed within four different molecular functions, namely catalytic activity (GO:0003824) (58.8\%), binding (GO:0005488) (29.4\%), molecular function regulator (GO:0098772) (5.9\%) and molecular transducer activity (GO:0060089) (5.9\%). These proteins were involved in four molecular processes: cellular process (GO:0009987) $(46.4 \%)$, metabolic process (GO:0008152) (42.9\%), response to stimulus (GO:0050896) (7.1\%) and localization (GO:0051179) (3.6\%). There was identified a total of 15 pathways related to those differentially expressed proteins, being glycolysis (P00024) the most represented with $25 \%$. Finally, nine protein classes were identified, being oxidoreductase (PC00176) the most represented (26.3\%), followed by calcium-binding protein (PC00060) and signaling molecule (PC00207) (15.8\% each).

No proteins were found to be differentially modulated between HC and DM groups in both serum and saliva.

\subsection{Validation of Proteomic Results}

When haptoglobin $(\mathrm{Hp})$ was measured in serum, it was statistically significantly higher in dogs with DM (median (25-75th percentile)), (4.6 (3.66-5.77) g/L) than in healthy controls $(2.04(1.12-2.67) \mathrm{g} / \mathrm{L})$ $(p<0.001)$, as shown in Figure 2.

\section{Serum Haptoglobin}

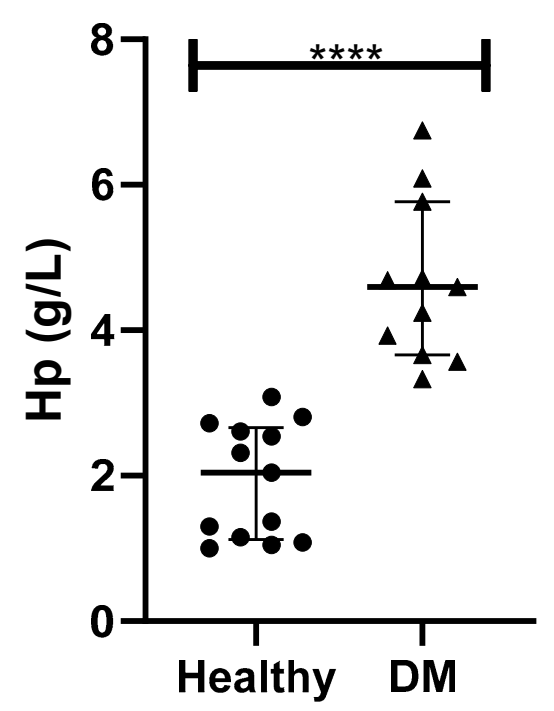

Figure 2. Serum haptoglobin in healthy dogs (Healthy) and dogs with type-1 diabetes mellitus (DM). Asterisks indicate differences of statistical relevance between the two groups $(* * * *: p>0.001)$.

In the case of S100A12 verification in saliva of dogs, most samples from HC and DM showed absorbance below the Blank standard.

\section{Discussion}

The present study demonstrates, for the first time, changes occurring in saliva and serum proteomes in dogs with diabetes mellitus. Almost twice proteins were identified in saliva compared to serum, which was in concordance with other studies [22]. None of the proteins differentially modulated in DM appeared in both serum and saliva and data about molecular function, biological process, pathways or protein class was different between the two biofluids. These findings were consistent with previous works in which matched saliva and serum samples were used [23]. Therefore, both biofluids present complementary information and may have diagnostic potential for DM. 
In serum, 16 proteins were found to be deregulated in DM in comparison to HC. According to PANTHER classification system, catalytic activity was the most represented molecular function. Similarly, metabolic process was the biological process most represented, including proteins such as transferrin, haptoglobin and apolipoprotein D. Transferrin is a negative acute-phase protein in dogs [24] and has anti-oxidant potential. DM is associated with mild inflammation [25], which may explain the down-regulation of transferrin observed in dogs with DM in the present study. However, there is a controversy on the status of transferrin in human diabetes, in which decreased, normal and increased levels have been reported [26-28]. To the best of the authors' knowledge, this is the first report describing transferrin concentrations in the serum of dogs with DM. Haptoglobin is a positive moderate acute phase protein in dogs, increasing in serum for 2-5-fold in inflammation and also has antioxidant capacity by binding the oxidant free hemoglobin [29]. Hp was selected for verification because was the most increased protein in serum of dogs with DM in comparison to HC and commercial methods are available for its measurement. In agreement with our results, Hp in serum has been proposed as a biomarker of virus-induced type $1 \mathrm{DM}$ as well as for autoimmune DM in rats [30]. Moreover, Hp gene has been associated with the increasing of DM complications in humans including nephropathy, cardiovascular diseases and retinopathies, as reviewed previously [31]. Our study showed lower apolipoprotein D (APOD) in serum of dogs with DM. Dogs with DM commonly have hypercholesterolemia with increased HDL [7] and a higher risk of atherosclerosis compared to healthy dogs [32]. In dogs, increases in apolipoproteins such as apolipoprotein E [33] and B [34] were reported in DM; however, to the best of the authors' knowledge, this is the first time in which APOD is related to DM in dogs. Thus, since various functions in several metabolic processes have been attributed to APOD [35], further studies are desirable to clarify its role in relation to canine DM.

A total of 26 proteins showed different abundance in saliva between HC and DM groups. According to PANTHER, the majority of differentially regulated proteins in saliva are associated with catalytic activity and binding molecular functions.

Heat shock cognate $71 \mathrm{kDa}$ protein (HSPA8), also known as Hsc70 or Hsp73, was the most dysregulated protein among those presenting catalytic activity in saliva, with a significant increase in dogs with DM. This. protein was reported to be in higher concentrations in plasma and retina of rats with DM when compared to healthy controls [36,37]. In humans, the polymorphisms of HSPA8 gene are significantly associated with the prevalence of hypertension [38], being hypertension also described in dogs with DM [39,40]. Additionally, distal renal tubular cells treated with $25 \mathrm{mM}$ glucose showed higher increased levels of HSP70 in comparison to untreated ones (5 mM glucose) [41]. Furthermore, concentrations in HSPA8 levels were associated with cancers, neurodegenerative diseases and ageing, among other conditions [42,43]. Besides, other potential biomarkers having catalytic activity that were significantly altered in saliva of dogs with DM, including triosephosphate isomerase (TPI1) [44] and (ENO2) [45], were previously related to human DM. In the proteins related to binding molecular function, S100A proteins-a family of calcium-binding proteins involved in innate immune responsewere among the most up-regulated in saliva of dogs with canine DM in the present study. Our results are in agreement to previous studies reporting higher levels of S100A9 in saliva of diabetic human adults [46] and children [16], in which S100A9 were proposed as a predictive factor for diabetes-related microvascular complications $[46,47]$. Similarly, increased plasma S100A12 has been related to diabetic retinopathy and might predict future major adverse endpoints in human diabetic patients [48].

Since S100A12 protein was the protein most up-regulated in saliva in DM in our study, we aimed to verify our results using a commercially available ELISA kit in an independent sample set. However, we were unable to validate our proteomic results since most samples were observed to be below the Blank standard. S100A2 in saliva has been proposed as a candidate biomarker for the early detection of oral squamous cell carcinomas in humans [49] and S100A11 is overexpressed in several human cancers tissues [50,51], although to the author's knowledge there are no reports that evaluate these two proteins in DM in humans. 
Calmodulins such as CALM2 and CALM3 are calcium-binding messengers implied in the control of insulin release from the beta cells [52]. Transgenic mice lines with alterations in CALM gene resulting in increased CALM levels in beta cells promoted the development of severe diabetes mellitus within hours of birth [53], which is in concordance with our results showing higher CALM in dogs with DM. In humans, calcium/calmodulin-dependent protein kinase II has been proved to be modulated by oxidation in several conditions including asthma, cardiovascular diseases, acute ischemic stroke, cancer and DM, as reviewed elsewhere [54]. Although CALM has been isolated and purified from dog's pancreas [55], their presence in saliva and possible relationship with canine DM is described here for the first time.

The present study has some limitations. First, although the sample size was higher than the minimum of three replicates required for proteomics studies and is in accordance with other studies [56-58], it is relative small and a power analysis test was not performed. Therefore, this should be considered as a pilot study and our results should be further confirmed and validated in larger cohorts. In case of serum, a verification of the results obtained for one protein, the haptoglobin, was made with a spectrophotometric method in a larger number of samples; however, in saliva, the ELISA kit used for the verification of the S100A12, which was the protein that showed the larger variation, was not sensitive enough for the detection of this protein when a larger number of samples were analyzed. Ideally, more sensitive immune-assays should be developed for the measurement of this analyte in saliva samples. Another limitation is that dogs of different breeds, body mass index and sex were used in our study, being further studies needed to evaluate their possible influence in DM proteomes [59-62].

\section{Methods}

Ethics approval: All the procedures were written-approved by the Ethics Committees of the University of Murcia and Ministry of agriculture, livestock, fishing and aquaculture, Region of Murcia (A13170503). Written informed consents were obtained from the animals' owners. Availability of data and materials: The datasets used and analyzed during the current study are available from the corresponding author on reasonable request.

\subsection{Animals}

A total of 10 client-owned dogs presented to private veterinary clinics of Murcia Region, Spain, during 2019 were involved in this study. Five animals ( 3 females; 3 mixed breeds, 1 Pinscher and 1 German shepherd; aged $8.6 \pm 3.6$ years) were classified as healthy based on hematology, biochemistry and a complete physical examination and included as the healthy control group (HC). Five animals (4 females; 4 mixed breeds and 1 Yorkshire Terrier; $9.6 \pm 1.98$ years old) were diagnosed with diabetes mellitus based on clinical signs including polyuria, polydipsia and polyphagia and laboratory findings including glycosuria and hyperglycemia (glucose $>200 \mathrm{mg} / \mathrm{dL}$ ) as previously described [63] and therefore included in diabetes mellitus (DM) group (Table 3). All DM dogs responded to insulin treatment, being suggestive of insulin-dependent DM (type 1-DM). In all cases, dogs were excluded if they were suspected to be affected by concurrent diseases based on physical examination and laboratory analyses and if gingivitis was detected. 
Table 3. Clinical history and main exploratory findings in dogs with diabetes mellitus (DM) and healthy controls $(\mathrm{H})$.

\begin{tabular}{|c|c|c|c|c|c|c|c|}
\hline ID & Sex & Age (y) & Breed & $\begin{array}{l}\text { Body Weight } \\
\text { (kg)/Diet }\end{array}$ & $\begin{array}{l}\text { Glucose } \\
\text { (mg/dL) }\end{array}$ & $\begin{array}{l}\text { Fructosamine } \\
(\mu \mathrm{mol} / \mathrm{L})\end{array}$ & Clinical Signs \\
\hline DM1 & Female & 12 & Mixed breed & 9.5/Dry food & 320 & 387 & $\begin{array}{c}\text { Diabetic } \\
\text { Retinopathy } \\
\text { PU-PD-PF }\end{array}$ \\
\hline DM2 & Female (neutered) & 10 & Mixed breed & 14.5/Dry food & 337 & 561 & $\begin{array}{c}\text { Diabetic } \\
\text { Retinopathy } \\
\text { PU-PD-PF }\end{array}$ \\
\hline DM4 & Male & 10 & Mixed breed & 20/Dry food & 277 & 497 & PU-PD-PF \\
\hline DM5 & Female & 6.5 & $\begin{array}{c}\text { Yorkshire } \\
\text { Terrier }\end{array}$ & 3/Dry food & 212 & 401 & PU-PD-PF \\
\hline $\mathrm{H} 1$ & Male & 7 & Poodle & 5.7/mixed & 103 & 267 & - \\
\hline $\mathrm{H} 2$ & Male (neutered) & 13 & Mixed breed & 14/Dry food & 98 & 181 & - \\
\hline
\end{tabular}

PU-PD-PF: polyuria, polydipsia and polyphagia. Reference ranges: $70-110 \mathrm{mg} / \mathrm{dL}$ for glucose and $162-310 \mu \mathrm{mol} / \mathrm{L}$ for fructosamine.

\subsection{Saliva and Serum Sampling}

Animals did not eat or exercise for at least two hours prior to their participation in the study. Saliva samples were obtained as previously reported [64] immediately before blood collection for routine clinical biochemical analyses. Saliva was collected using a small sponge placed in the mouth of the dog until it was thoroughly moistened. The sponge was then tucked into collection devices (Salivette saliva collection tube/V-Bottom, Sarstedt, Aktiengesellschaft \& Co, Nümbrecht, Germany) and centrifuged $(3000 \times g)$ for $10 \mathrm{~min}, 4^{\circ} \mathrm{C}$. Finally, the supernatants were passed to plastic tubes (Eppendorf, Hamburg, Germany) and stored at $-80^{\circ} \mathrm{C}$ until analysis.

Surplus serum samples, remaining after routine clinical biochemical analyses, were used for the present study. Whole blood was obtained by venipuncture of the jugular or cephalic vein and stored in tubes containing a coagulation activator and a gel separator until visible clot reaction. Samples were centrifuged $(3500 \times g, 10 \mathrm{~min})$ and the supernatant was stored $-80^{\circ} \mathrm{C}$ until analysis.

\subsection{Proteomics Study of Saliva and Serum Samples and LC-MS/MS Analysis}

For each sample, thirty-five $\mu \mathrm{g}$ of proteins were subjected to reduction, alkylation, digestion and labelling using 6-plex Tandem Mass Tag reagents, according to manufacturer instructions (Thermo Scientific, New York, NY, USA) as described previously [18,19]. A pool with $35 \mu \mathrm{g}$ protein from each sample was included as internal standard and data from each sample and protein was calculated as a ratio of the internal standard.

The liquid chromatography tandem mass spectrometry (LC-MS/MS) analysis was performed using Dionex Ultimate 3000 RSLC nano-flow system (Dionex, Camberley, UK) and Orbitrap Q Exactive Plus mass spectrometer (Thermo Fisher Scientific, Waltham, MA, USA) as described elsewhere [58]. For peptide identification and relative quantification, SEQUEST algorithm, Proteome Discoverer (version 2.0., Thermo Fisher Scientific), was used. NCBI database search against Canis Lupus FASTA files was performed considering two trypsin missed cleavage sites, precursor tolerance of $10 \mathrm{ppm}$ and fragment mass tolerance of $0.02 \mathrm{Da}$. The false discovery rate (FDR) for peptide identification was set at $1 \%$ and Percolator algorithm within the Proteome Discoverer workflow was used.

\subsection{Statistical Analysis}

Proteins with less than two unique peptides and outliers were removed from the analysis. Sample outliers were detected per each group and protein using Dixon's test from $R$ package outliers 
v0.14 [65]. If any sample outlier was significant $(p<0.05)$ it was removed from further analysis. Then, proteins that were missing data in $>2$ samples per group were removed. To test the difference in protein abundance between groups Wilcoxon-Mann-Whitney test was performed, since the majority of the analyzed proteins did not follow normal distribution, tested by Shapiro-Wilk test. Fold change between two groups was calculated as mean DM group divided by mean HC group. All statistics were performed using R v3.2.2 [66].

PCA and heatmaps were designed using R packages ggplot2 v3.1.1 [67] and pheatmap v1.0.12 [68], respectively.

Proteins GI accession numbers were converted into official gene symbol either by UniProtKB ID mapping (https://www.uniprot.org/uploadlists/), DAVID conversion tool (https://david.ncifcrf. gov/conversion.jsp) or from SEQUEST search engine implemented into Proteome Discoverer [21,69]. Genes encoding the differentially abundant proteins between DM and HC groups were used to determine the GO terms over-represented in DM using Protein Analysis Through Evolutionary Relationships (PANTHER) classification tool (http://www.pantherdb.org/).

For the validation of haptoglobin in serum, distribution of data was evaluated using D'Agostino \& Pearson omnibus normality test. Since the data were not normally distributed, the non-parametric statistical Mann Whitney U (two-way) test was used to compare serum haptoglobin between the different groups.

\subsection{Validation of Proteomic Results}

Haptoglobin $(\mathrm{Hp})$ concentrations in serum were determined by use of the spectrophotometric hemoglobin-binding method with the use of a commercial kit (Tridelta Development Ltd., Kildare, Ireland), following manufacturer's instructions. The method was previously validated for its use in canine samples [70] and an automatic analyzer (AU 600 automated biochemical analyzer, Olympus, Minneapolis, MI, USA) was employed for Hp measurement. Hp was expressed in g/L.

For the verification of S100A12 protein in saliva, a commercially available ELISA Kit for S100A2 Calcium Binding Protein A12 (S100A12) (SEB080Hu, Cloud Clone, TX, USA) following manufacturer's instructions.

For the validation of Hp and S100A12, serum and saliva samples, respectively, from 13 healthy (6 different breeds) and 11 dogs diagnosed with DM (4 different breeds) were employed.

\section{Conclusions}

In conclusion, the data from the present study highlights the potential of the TMT-based approach for the screening of changes in serum and saliva proteome in dogs with diabetes mellitus. Serum proteome analysis pointed out alterations in oxidative status, defense and inflammation proteins, being some of them such as transferrin and Hp not described previously in canine DM. Saliva proteome evidenced changes in cellular and metabolic processes related to the pathogenesis of DM, insulin resistance and possible relationship with the increased susceptibility to secondary diseases due to DM. Some of the modulated proteins in saliva such as HSPA8 or S100A9 have been previously related to DM complications such as hypertension or micro-vascular alterations, while others such as S100A2 and S100A11 are described in DM here for the first time.

Based on these results, from the clinical point of view, the proteins identified here are a useful tool to improve the knowledge about the pathogenesis of DM and may have potential use as biomarkers of this disease.

Supplementary Materials: The following are available online at http://www.mdpi.com/2076-2615/10/12/2261/s1, Figure S1. Principal component analysis (PCA) results from serum samples. Figure S2. Heatmap showing the relative abundance (color) of serum proteins in healthy (HC) and dogs with diabetes mellitus (DM). Figure S3. Principal component analysis (PCA) results from saliva samples. Figure S4. Heatmap showing the relative abundance (color) of saliva proteins in healthy (HC) and dogs with diabetes mellitus (DM). Table S1. MS/MS spectra info, peptide spectrum matches (PSMs), identified peptides, proteins and protein groups in serum samples. Table S2. MS/MS spectra info, peptide spectrum matches (PSMs), identified peptides, proteins and protein 
groups in saliva samples. Table S3. Serum proteins identified in dogs with diabetes mellitus (DM) and healthy controls (HC).

Author Contributions: Conceptualization, S.M.-S., V.M. and A.T.; methodology, A.H.; software, A.H. and A.G.; validation, M.D.C.-A.; investigation, L.F.-M.; resources, J.J.C and V.M.; writing-original draft preparation, L.F.-M.; writing-review and editing, L.F.-M., S.M.-S., A.T., J.J.C.; funding acquisition, A.T., V.M., and J.J.C. All authors have read and agreed to the published version of the manuscript.

Funding: LFM and MDCA were granted with predoctoral contract 'FPU' of University of Murcia, Spain. AT has a post-doctoral fellowship "Ramón y Cajal" (RYC-2017-22992) supported by the Ministerio de Economía y Competitividad, Agencia Estatal de Investigación (AEI), Spain, and The European Social Fund (ESF). This work was supported by a grant from the Program for Research Groups of Excellence of the Seneca Foundation, Murcia, Spain (grant 19894/GERM/15), by the Seneca Foundation-Agency of Science and Technology of the Region of Murcia through the Subprogram of Support to the Scientific Leadership and the Transition to the Independent Investigation (20649/JLI/18) and European Commission ERA chair FP7 grant (VetMedZg \#621394).

Acknowledgments: The authors would like to thank the pet owners and their colleagues that kindly agreed to collaborate in this study.

Conflicts of Interest: The authors declare no conflict of interest.

\section{Abbreviations}

ApoD: apolipoprotein D; CALM: calmodulin; DM: diabetes mellitus; ENO2: enolase 2; FDR: false discovery rate; HC: healthy controls; Hp: haptoglobin; HSPA8: heat shock cognate 71 kDa protein; PANTHER: Protein Analysis Through Evolutionary Relationships; TMT: Tandem Mass Tags; TPI: triosephosphate isomerase.

\section{References}

1. Guptill, L.; Glickman, L. Time Trends and Risk Factors for Diabetes Mellitus in Dogs: Analysis of Veterinary Medical Data Base Records (1970-1999). Veter. J. 2003, 165, 240-247. [CrossRef]

2. Davison, L.J.; Herrtage, M.E.; Catchpole, B. Study of 253 dogs in the United Kingdom with diabetes mellitus. Veter. Rec. 2005, 156, 467-471. [CrossRef] [PubMed]

3. McAllister, M.; Breuninger, K.; Spofford, N.; Yang, M.; Trevejo, R. State of Pet Health 2016 Report. pp. 1-21. Available online: https://www.banfield.com/Banfield/media/PDF/Downloads/soph/Banfield-State-of-PetHealth-Report-2016.pdf (accessed on 24 March 2020).

4. Davison, L.J. Diabetes mellitus and pancreatitis-cause or effect? J. Small Anim. Pr. 2015, 56, 50-59. [CrossRef] [PubMed]

5. Kleinert, M.; Clemmensen, C.; Hofmann, S.M.; Moore, M.C.; Renner, S.; Woods, S.C.; Huypens, P.; Beckers, J.; De Angelis, M.H.; Schürmann, A.; et al. Animal models of obesity and diabetes mellitus. Nat. Rev. Endocrinol. 2018, 14, 140-162. [CrossRef] [PubMed]

6. Moshref, M.; Tangey, B.; Gilor, C.; Papas, K.K.; Williamson, P.; Loomba-Albrecht, L.; Sheehy, P.; Kol, A. Concise Review: Canine Diabetes Mellitus as a Translational Model for Innovative Regenerative Medicine Approaches. Stem Cells Transl. Med. 2019, 8, 450-455. [CrossRef]

7. Hess, R.S.; Saunders, H.M.; Van Winkle, T.J.; Ward, C.R. Concurrent disorders in dogs with diabetes mellitus: 221 cases (1993\&1998). J. Am. Veter Med. Assoc. 2000, 217, 1166-1173. [CrossRef]

8. Cerón, J.J. Acute phase proteins, saliva and education in laboratory science: An update and some reflections. BMC Veter Res. 2019, 15, 197. [CrossRef]

9. Sivadasan, P.; Gupta, M.K.; Sathe, G.J.; Balakrishnan, L.; Palit, P.; Gowda, H.; Suresh, A.; Kuriakose, M.A.; Sirdeshmukh, R. Human salivary proteome-a resource of potential biomarkers for oral cancer. J. Proteom. 2015, 127, 89-95. [CrossRef]

10. Kumar, S.; Padmashree, S.; Jayalekshmi, R. Correlation of salivary glucose, blood glucose and oral candidal carriage in the saliva of type 2 diabetics: A case-control study. Contemp. Clin. Dent. 2014, 5, 312. [CrossRef]

11. Sashikumar, R.; Kannan, R. Salivary glucose levels and oral candidal carriage in type II diabetics. Oral Surg. Oral Med. Oral Pathol. Oral Radiol. Endodontology 2010, 109, 706-711. [CrossRef]

12. Gupta, S.; Sandhu, S.V.; Bansal, H.; Sharma, D. Comparison of Salivary and Serum Glucose Levels in Diabetic Patients. J. Diabetes Sci. Technol. 2014, 9, 91-96. [CrossRef] [PubMed]

13. Kim, S.W.; Choi, J.-W.; Yun, J.W.; Chung, I.-S.; Cho, H.C.; Song, S.-E.; Im, S.-S.; Song, D.-K. Proteomics approach to identify serum biomarkers associated with the progression of diabetes in Korean patients with abdominal obesity. PLoS ONE 2019, 14, e0222032. [CrossRef] [PubMed] 
14. Pappa, E.; Vastardis, H.; Mermelekas, G.; Gerasimidi-Vazeou, A.; Zoidakis, J.; Vougas, K. Saliva Proteomics Analysis Offers Insights on Type 1 Diabetes Pathology in a Pediatric Population. Front. Physiol. $2018,9$. [CrossRef] [PubMed]

15. Bencharit, S.; Baxter, S.S.; Carlson, J.; Byrd, W.C.; Mayo, M.V.; Border, M.B.; Kohltfarber, H.; Urrutia, E.; Howard-Williams, E.L.; Offenbacher, S.; et al. Salivary proteins associated with hyperglycemia in diabetes: A proteomic analysis. Mol. BioSyst. 2013, 9, 2785-2797. [CrossRef] [PubMed]

16. Cabras, T.; Pisano, E.; Mastinu, A.; Denotti, G.; Pusceddu, P.P.; Inzitari, R.; Fanali, C.; Nemolato, S.; Castagnola, M.; Messana, I. Alterations of the Salivary Secretory Peptidome Profile in Children Affected by Type 1 Diabetes. Mol. Cell. Proteom. 2010, 9, 2099-2108. [CrossRef]

17. Tvarijonaviciute, A.; Barić-Rafaj, R.; Horvatić, A.; Muñoz-Prieto, A.; Guillemin, N.; Lamy, E.; Tumpa, A.; Ceron, J.; Martínez-Subiela, S.; Mrljak, V. Identification of changes in serum analytes and possible metabolic pathways associated with canine obesity-related metabolic dysfunction. Veter. J. 2019, 244, 51-59. [CrossRef]

18. Franco-Martínez, L.; Tvarijonaviciute, A.; Horvatić, A.; Guillemin, N.; Cerón, J.J.; Escribano, D.; Eckersall, D.; Kocaturk, M.; Yilmaz, Z.; Lamy, E.; et al. Changes in salivary analytes in canine parvovirus: A high-resolution quantitative proteomic study. Comp. Immunol. Microbiol. Infect. Dis. 2018, 60, 1-10. [CrossRef]

19. Martínez-Subiela, S.; Horvatić, A.; Escribano, D.; Pardo-Marin, L.; Kocaturk, M.; Mrljak, V.; Burchmore, R.; Cerón, J.J.; Yilmaz, Z. Identification of novel biomarkers for treatment monitoring in canine leishmaniosis by high-resolution quantitative proteomic analysis. Veter. Immunol. Immunopathol. 2017, 191, 60-67. [CrossRef]

20. Franco-Martínez, L.; Tvarijonaviciute, A.; Horvatić, A.; Guillemin, N.; Bernal, L.J.; Barić Rafaj, R.; Ceron, J.J.; Thomas, M.d.C.; Lopez, M.C.; Tecles, F.; et al. Changes in saliva of dogs with canine leishmaniosis: A proteomic approach. Vet. Parasitol. 2019, 272, 44-52. [CrossRef]

21. Franco-Martínez, L.; Villar, M.; Tvarijonaviciute, A.; Escribano, D.; Bernal, L.J.; Cerón, J.J.; Thomas, M.D.C.; Mateos-Hernández, L.; Tecles, F.; De La Fuente, J.; et al. Serum proteome of dogs at subclinical and clinical onset of canine leishmaniosis. Transbound. Emerg. Dis. 2020, 67, 318-327. [CrossRef]

22. Loo, J.; Yan, W.; Ramachandran, P.; Wong, D. Comparative Human Salivary and Plasma Proteomes. J. Dent. Res. 2010, 89, 1016-1023. [CrossRef] [PubMed]

23. Franco-Martínez, L.; Gelemanović, A.; Horvatić, A.; Contreras-Aguilar, M.D.; Dabrowski, R.; Mrljak, V.; Ceron, J.J.; Martinez-Subiela, S.; Tvarijonaviciute, A. Changes in Serum and Salivary Proteins in Canine Mammary Tumors. Animals 2020, 10, 741. [CrossRef] [PubMed]

24. Cerón, J.J.; Eckersall, P.D.; Martínez-Subiela, S. Acute phase proteins in dogs and cats: Current knowledge and future perspectives. Veter. Clin. Pathol. 2005, 34, 85-99. [CrossRef] [PubMed]

25. Ricart, W.; López-Bermejo, A.; Ricart, W. Cross-Talk Between Iron Metabolism and Diabetes. Diabetes 2002, 51, 2348-2354. [CrossRef]

26. McMillan, D.E. Increased levels of acute-phase serum proteins in diabetes. Metabolism 1989, 38, $1042-1046$. [CrossRef]

27. Awadallah, R.; El-Dessoukey, E.A.; Doss, H.; Khalifa, K.; Elhawary, Z. Blood-reduced glutathione, serum ceruloplasmin and mineral changes in juvenile diabetes. Eur. J. Nutr. 1978, 17, 79-83. [CrossRef]

28. Golizeh, M.; Lee, K.; Ilchenko, S.; Ösme, A.; Bena, J.; Sadygov, R.G.; Kashyap, S.R.; Kasumov, T. Increased serotransferrin and ceruloplasmin turnover in diet-controlled patients with type 2 diabetes. Free. Radic. Biol. Med. 2017, 113, 461-469. [CrossRef]

29. Lim, Y.K.; Jenner, A.; Ali, A.; Wang, Y.; Hsu, S.I.-H.; Chong, S.M.; Baumman, H.; Halliwell, B.; Lim, S.-K. Haptoglobin reduces renal oxidative DNA and tissue damage during phenylhydrazine-induced hemolysis. Kidney Int. 2000, 58, 1033-1044. [CrossRef]

30. Kruger, A.; Yang, C.; Tam, S.W.; Hinerfeld, D.; Evans, J.E.; Green, K.M.; Leszyk, J.; Yang, K.; Guberski, D.L.; Mordes, J.P.; et al. Haptoglobin as an early serum biomarker of virus-induced autoimmune type 1 diabetes in biobreeding diabetes resistant and LEW1.WR1 rats. Exp. Biol. Med. 2010, 235, 1328-1337. [CrossRef]

31. Sadrzadeh, S.H.; Bozorgmehr, J. Haptoglobin Phenotypes in Health and Disorders. Pathol. Patterns Rev. 2004, 121, S97-S104. [CrossRef]

32. Hess, R.S.; Kass, P.H.; Van Winkle, T.J. Association between Diabetes Mellitus, Hypothyroidism or Hyperadrenocorticism, and Atherosclerosis in Dogs. J. Vet. Intern. Med. 2003, 17, 489-494. [CrossRef] [PubMed] 
33. Gleeson, J.M.; Hejazi, J.S.; Kwong, L.; Chan, I.F.; Le, T.; Alberts, A.W.; Wilson, D.E. Plasma apolipoprotein $\mathrm{E}$, high density lipoprotein (HDL) and urinary mevalonate excretion in pancreatectomized diabetic dogs: Effects of insulin and lovastatin. Atherosclerosis 1990, 84, 1-12. [CrossRef]

34. Seage, E.; Drobatz, K.; Hess, R.S. Spectrophotometry and Ultracentrifugation for Measurement of Plasma Lipids in Dogs with Diabetes Mellitus. J. Vet. Intern. Med. 2017, 32, 93-98. [CrossRef] [PubMed]

35. Rassart, E.; Bedirian, A.; Do Carmo, S.; Guinard, O.; Sirois, J.; Terrisse, L.; Milne, R. Apolipoprotein D. Biochim. Biophys. Acta. 2000, 1482, 185-198. [CrossRef]

36. Safaei, A.; Tavirani, M.R.; Azodi, M.Z.; Lashay, A.; Mohammadi, S.-F.; Broumand, M.G.; Peyvandi, A.; Okhovatian, F.; Peyvandi, H.; Rostami-Nejad, M. Diabetic Retinopathy and Laser Therapy in Rats: A Protein-Protein Interaction Network Analysis. J. Lasers Med. Sci. 2017, 8, S20-S21. [CrossRef]

37. Karthik, D.; Ilavenil, S.; Kaleeswaran, B.; Sunil, S.; Ravikumar, S. Proteomic Analysis of Plasma Proteins in Diabetic Rats by 2D Electrophoresis and MALDI-TOF-MS. Appl. Biochem. Biotechnol. 2012, 166, 1507-1519. [CrossRef]

38. Yamada, Y.; Oguri, M.; Kato, K.; Yokoi, K.; Watanabe, S.; Metoki, N.; Yoshida, H.; Satoh, K.; Aoyagi, Y.; Nishigaki, Y.; et al. Association of polymorphisms of THBS2 and HSPA8 with hypertension in Japanese individuals with chronic kidney disease. Mol. Med. Rep. 2009, 2, 205-211. [CrossRef]

39. Priyanka, M.; Jeyaraja, K.; Thirunavakkarasu, P.S. Abnormal renovascular resistance in dogs with diabetes mellitus: Correlation with glycemic status and proteinuria. Iran. J. Veter. Res. 2018, 19, 304-309.

40. Herring, I.; Panciera, D.; Werre, S. Longitudinal Prevalence of Hypertension, Proteinuria, and Retinopathy in Dogs with Spontaneous Diabetes Mellitus. J. Veter. Intern. Med. 2014, 28, 488-495. [CrossRef]

41. Aluksanasuwan, S.; Sueksakit, K.; Fong-Ngern, K.; Thongboonkerd, V. Role of HSP60 (HSPD1) in diabetes-induced renal tubular dysfunction: Regulation of intracellular protein aggregation, ATP production, and oxidative stress. FASEB J. 2017, 31, 2157-2167. [CrossRef]

42. Mayer, M.P.; Bukau, B. Hsp70 chaperones: Cellular functions and molecular mechanism. Cell. Mol. Life Sci. 2005, 62, 670-684. [CrossRef] [PubMed]

43. Wang, X.; Wang, Q.; Lin, H.; Li, S.; Sun, L.; Yang, Y. HSP72 and gp96 in gastroenterological cancers. Clin. Chim. Acta 2013, 417, 73-79. [CrossRef] [PubMed]

44. Chen, J.-Y.; Chou, H.-C.; Chen, Y.-H.; Chan, H.-L. High glucose-induced proteome alterations in hepatocytes and its possible relevance to diabetic liver disease. J. Nutr. Biochem. 2013, 24, 1889-1910. [CrossRef] [PubMed]

45. Sreekumar, R.; Halvatsiotis, P.; Schimke, J.C.; Nair, K.S. Gene Expression Profile in Skeletal Muscle of Type 2 Diabetes and the Effect of Insulin Treatment. Diabetes 2002, 51, 1913-1920. [CrossRef]

46. Caseiro, A.; Ferreira, R.; Padrão, A.; Quintaneiro, C.; Pereira, A.; Marinheiro, R.; Vitorino, R.; Amado, F. Salivary Proteome and Peptidome Profiling in Type 1 Diabetes Mellitus Using a Quantitative Approach. J. Proteome Res. 2013, 12, 1700-1709. [CrossRef]

47. Lim, R.R.; Vaidya, T.; Gadde, S.G.; Yadav, N.K.; Sethu, S.; Hainsworth, D.P.; Mohan, R.R.; Ghosh, A.; Chaurasia, S.S. Correlation between systemic S100A8 and S100A9 levels and severity of diabetic retinopathy in patients with type 2 diabetes mellitus. Diabetes Metab. Syndr. Clin. Res. Rev. 2019, 13, 1581-1589. [CrossRef]

48. Dong, N.; Shi, H.; Xu, B.; Cai, Y. Increased Plasma S100A12 Levels Are Associated with Diabetic Retinopathy and Prognostic Biomarkers of Macrovascular Events in Type 2 Diabetic Patients. Investig. Opthalmology Vis. Sci. 2015, 56, 4177. [CrossRef]

49. Shan, J.; Sun, Z.; Yang, J.; Xu, J.; Shi, W.; Wu, Y.; Fan, Y.; Li, H.-Q. Discovery and preclinical validation of proteomic biomarkers in saliva for early detection of oral squamous cell carcinomas. Oral Dis. 2018, 25, 97-107. [CrossRef]

50. Li, Y.; Zhang, J. Expression of S100A11 is a Prognostic Factor for Disease-free Survival and Overall Survival in Patients with High-grade Serous Ovarian Cancer. Appl. Immunohistochem. Mol. Morphol. 2017, 25, 110-116. [CrossRef]

51. Gabril, M.; Girgis, H.; Scorilas, A.; Rotondo, F.; Wala, S.; Bjarnason, G.A.; Ding, Q.; Evans, A.; Tawedrous, E.; Pasic, M.; et al. S100A11 is a potential prognostic marker for clear cell renal cell carcinoma. Clin. Exp. Metastasis 2015, 33, 63-71. [CrossRef]

52. Sabatini, P.V.; Speckmann, T.; Lynn, F.C. Friend and foe: Beta-cell $\mathrm{Ca}^{2+}$ signaling and the development of diabetes. Mol. Metab. 2019, 21, 1-12. [CrossRef] [PubMed] 
53. Epstein, P.N.; Overbeek, P.A.; Means, A.R. Calmodulin-induced early-onset diabetes in transgenic mice. Cell 1989, 58, 1067-1073. [CrossRef]

54. Qu, J.; Mei, Q.; Niu, R. Oxidative CaMKII as a potential target for inflammatory disease (Review). Mol. Med. Rep. 2019, 20, 863-870. [CrossRef] [PubMed]

55. Bartelt, D.C.; Wolff, D.J.; Scheele, G.A. Calmodulin-binding proteins and calmodulin-regulated enzymes in dog pancreas. Biochem. J. 1986, 240, 753-763. [CrossRef] [PubMed]

56. Westermeier, R.; Naven, T.; Hopker, H.R. Proteomics in Practice: A Guide to Successful Experimental Design; Wiley-VCH: Hoboken, NJ, USA, 2008.

57. Jacobsen, S.; Adler, D.; Bundgaard, L.; Sørensen, M.A.; Andersen, P.H.; Bendixen, E. The use of liquid chromatography tandem mass spectrometry to detect proteins in saliva from horses with and without systemic inflammation. Veter. J. 2014, 202, 483-488. [CrossRef]

58. Horvatić, A.; Guillemin, N.; Kaab, H.; McKeegan, D.; O’Reilly, E.; Bain, M.; Kuleš, J.; Eckersall, P.D. Quantitative proteomics using tandem mass tags in relation to the acute phase protein response in chicken challenged with Escherichia coli lipopolysaccharide endotoxin. J. Proteom. 2019, 192, 64-77. [CrossRef]

59. Heeley, A.M.; O’Neill, D.G.; Davison, L.J.; Church, D.B.; Corless, E.K.; Brodbelt, D.C. Diabetes mellitus in dogs attending UK primary-care practices: Frequency, risk factors and survival. Canine Med. Genet. 2020, 7, 1-19. [CrossRef]

60. Lucena, S.; Coelho, A.; Capela-Silva, F.; Tvarijonaviciute, A.; Lamy, E. The Effect of Breed, Gender, and Acid Stimulation in Dog Saliva Proteome. BioMed Res. Int. 2018, 2018, 1-12. [CrossRef]

61. Hong, H.-R.; Oh, Y.; Kim, Y.J.; Seo, K.W. Salivary alpha-amylase as a stress biomarker in diseased dogs. J. Veter. Sci. 2019, 20, e46. [CrossRef]

62. Iacopetti, I.; Perazzi, A.; Badon, T.; Bedin, S.; Contiero, B.; Ricci, R. Salivary pH, calcium, phosphorus and selected enzymes in healthy dogs: A pilot study. BMC Veter. Res. 2017, 13, 330. [CrossRef]

63. Durocher, L.L.; Hinchcliff, K.; DiBartola, S.P.; Johnson, S.E. Acid-base and hormonal abnormalities in dogs with naturally occurring diabetes mellitus. J. Am. Veter. Med Assoc. 2008, 232, 1310-1320. [CrossRef]

64. Parra, M.D.; Tecles, F.; Subiela, S.M.; Cerón, J.J. C-Reactive Protein Measurement in Canine Saliva. J. Veter. Diagn. Investig. 2005, 17, 139-144. [CrossRef]

65. Komsta, L. Package Outliers. 2015. Available online: https://www.google.com.hk/url?sa=t\&rct=j\& $\mathrm{q}=\&$ esrc $=$ s\&source=web\&cd=\&ved=2ahUKEwiQ3P365avtAhVQ1VkKHUxcAIMQFjAAegQIBBAC\& url=https $\% 3 \mathrm{~A} \% 2 \mathrm{~F} \% 2 \mathrm{Fcran} . \mathrm{r}-$ project.org $\% 2 \mathrm{Fweb} \% 2 \mathrm{Fpackages} \% 2$ Foutliers $\% 2$ Foutliers.pdf\&usg= AOvVaw1OsjFhE2OldfePZSksPWSa (accessed on 26 October 2020).

66. R Core Team. R: A Language and Environment for Statistical Computing; R Found Statistical Computing: Vienna, Austria, 2013.

67. Wickham, H. Ggplot2: Elegant Graphics for Data Analysis; Springer: New York, NY, USA, 2009.

68. Kolde, R. Pheatmap: Pretty Heatmaps in R Package. R Packag Version 61. 2012. Available online: https://rdrr.io/cran/pheatmap/ (accessed on 26 October 2020).

69. Doncheva, N.T.; Morris, J.H.; Gorodkin, J.; Jensen, L.J. Cytoscape StringApp: Network Analysis and Visualization of Proteomics Data. J. Proteome Res. 2019, 18, 623-632. [CrossRef]

70. Eckersall, P.D.; Duthie, S.; Safi, S.; Moffatt, D.; Horadagoda, N.U.; Doyle, S.; Perton, R.; Bennett, D.; Fitzpatrick, J.L. An automated biochemical assay for haptoglobin: Prevention of interference from albumin. Comp. Haematol. Int. 1999, 9, 117-124. [CrossRef]

Publisher's Note: MDPI stays neutral with regard to jurisdictional claims in published maps and institutional affiliations.

(C) 2020 by the authors. Licensee MDPI, Basel, Switzerland. This article is an open access article distributed under the terms and conditions of the Creative Commons Attribution (CC BY) license (http://creativecommons.org/licenses/by/4.0/). 